Устінов А. А., аспірант Фонарьова Т. А., к.е.н., доцент

Петренко В. О., Д.т.Н., професор Національна металургійна академія Украӥни м. Дніпро, Україна

DOI: https://doi.org/10.30525/978-9934-26-107-7-10

\title{
СУЧАСНІ АСПЕКТИ ЗАБЕЗПЕЧЕННЯ КОНКУРЕНТОСПРОМОЖНОСТІ ІНТЕЛЕКТУАЛЬНОГО ПІДПРИЄМНИЦТВА В КОНТЕКСТІ СОЦІАЛЬНОЇ ВІДПОВІДАЛЬНОСТІ
}

В умовах кризових явищ, які протягом тривалого часу спостерігаються в Україні, формування соціальної відповідальності всіх суб'єктів держави, зокрема, бізнесу набуває особливого значення. Адже, можливість отримання прибутку, набуття конкурентних переваг не виключає, а навпаки, зумовлює відповідальність підприємця перед споживачем та суспільством. Усвідомлення соціальної відповідальності спонукає представників бізнесових структур до пошуку більш екологічних та енергозберігаючих технологій, до ведення сумлінної ділової практики, розвитку людських ресурсів через практику найму, навчання, встановлення справедливого рівня заробітної плати, безпеку праці, стабільність та порядок звільнень. Такі підприємства мають соціально-орієнтовану місію, яка формується виходячи 3 аспектів, які допомагають розкрити потенціал працівників, які направлені на виробництво або надання послуг 3 якісних продуктів та матеріалів, 3 мінімальним впливом на забруднення середовища, які дотримуються етичних правил в рекламі, зацікавлені в задоволеності клієнтів, а також у дотриманні прав інтелектуальної власності.

Розглянемо більш детально умови розвитку та підвищення конкурентоспроможності інтелектуального підприємництва в контексті соціальної відповідальності. 
Почнемо з правової відповідальності. Отже, у залежності від видів соціальних норм виділяють такі різновиди соціальної відповідальності: моральна, релігійна, дисциплінарна, політична, правова (юридична) тощо. Правова відповідальність настає у випадку порушення норм державно-організованого права. Вона має активний характер, оскільки передбачає активний психологічний вплив на порушника аж до застосування примусового фізичного впливу. Таким чином, соціальна та правова відповідальність співвідносяться як загальне та особливе. Отже, правова відповідальність - основний різновид соціальної [1].

Шлях перетворення інтелектуального продукту в товар дуже складний, результатом є об'єкти права інтелектуальної власності (OПIB). Саме тому особливого значення набуває охорона прав на об'єкти інтелектуальної власності. Ситуація яка склалася, нажаль, характеризується відсутністю в Україні механізму здійснення компенсації збитків від незаконного використання інтелектуальної власності за допомогою страхування. На відміну від компенсації, яка відбувається на підставі судового захисту, страхування створює можливість компенсувати збитки набагато швидше, оскільки саме рішення суду ще не означає, що воно одразу ж буде виконано порушником прав. Тому компенсація збитків за допомогою страхування є більш прийнятною формою захисту майнових прав власника інтелектуальної власності [2]. Отже, вирішення проблеми страхування об'єктів права інтелектуальної власності дозволить залучити нових клієнтів, отримати нові економічні можливості, та забезпечити підвищення конкурентоспроможності, як вітчизняних страхових компаній, так й інтелектуального підприємництва в Україні, що має велике соціально-економічне значення.

Другим важливим напрямом є діджиталізація суспільства. Інтелектуальне підприємництво знаходиться в авангарді процесу впровадження новітніх IT-технологій, цифровізації усіх аспектів діяльності, впровадження е-комерції, що несе в собі великий соціальний зміст. Отже, в таких умовах набуває особливого значення сфера відносин компанії зі спеціальними групами 
населення, зайнятості та поліпшення становища меншин, жінок, представників груп 3 обмеженими можливостями, а також співпраця з правозахисними організаціями.

Третім аспектом є впровадження концепції соціально-етичного маркетингу. На додаток до задоволення індивідуальних потреб і бажань клієнтів представники інтелектуального підприємництва прагнуть зберегти і поліпшити якісний життєвий рівень суспільства в цілому. Соціально-етична поведінка підприємців, спрямована на досягнення цих цілей, має як моральну, так i філософську сутність. При реалізації цієї концепції у виробничій програмі потрібно виділяти і постійно втілювати в життя заходи, що мають соціальне значення і вплив на навколишнє середовище, дуже важливо, щоб співробітники фірми могли б ототожнювати себе 3 цією концепцією. Фактором успіху $\epsilon$ накопичення необхідної кількості соціально-етичних дій, щоб надати бажаний імідж фірмі в цілому. Істотним джерелом небезпеки при використанні цієї концепції є те, що в багатьох випадках інтереси клієнтів, суспільства і фірми стикаються, а для їх узгодження приймаються компромісні рішення, які виявляються незадовільними для всіх учасників. Але це не свідчить проти концепції соціально-етичного маркетингу, а прояснює існуючі при цьому вимоги і шанси, які може відкрити для себе підприємство. Законодавчі заходи не повинні бути єдиною причиною соціальноетичних і не шкідливих для навколишнього середовища дій. Найчастіше можна за допомогою соціально-етичного маркетингу дійсно досягти переваг у конкурентній боротьбі і це слід підкреслити.

Четвертим аспектом $є$ організаційні структури управління (ОСУ). Якщо підприємство обрало інноваційний тип розвитку, його ОСУ повинні мати високий інноваційний потенціал 3 добре розвинутими структурними підрозділами. Найбільшу сприятливість до інновацій мають адаптивні ОСУ, вони гнучко перебудовуються відповідно до змін завдань і умов діяльності, проводять моніторинг останніх досягнень НТП, обгрунтовують доцільність інноваційних технологій та їх впровадження. 
Позитивний вплив на інноваційний потенціал організації робить децентралізація в прийнятті рішень, низький рівень формалізації і регламентації управлінських робіт, сучасні адаптивні форми OCУ [3].

Інший аспект стосується безпосередньо персоналу інтелектуальних бізнес-структур: сукупних навичок, знань і талантів співробітників, а також їх внутрішньої корпоративної культури, постійного навчання і вдосконалення. Такі підприємства розглядають своїх співробітників не як один із чинників виробництва, а як основний ресурс, як носія цінних ідей. Відповідно до зміни ролі людини в інтелектуальному підприємництві змінюються ставлення до співробітників, стиль керівництва і управлінські практики, що використовуються. Інтелектуальні бізнес-структури формують новий образ працівника - партнера-власника, який орієнтується не тільки на матеріальну, а й на моральну винагороду. Залучення співробітників до процесу прийняття рішень створює середовище, сприятливе для обміну думками, творчості, стимулюючу інноваційні підходи до вирішення проблем, максимально використовує можливості i знання кожного [4].

Наступним аспектом, який має важливе соціальне значення, $є$ захист навколишнього середовища та використання енергозберігаючих технологій. Інтелектуальне підприємництво здатне відповісти на ці виклики за рахунок використання трансферу технологій [5]. Це дає змогу розробляти та впроваджувати технології та інновації, які приносять як прибуток підприємцю, так й користь суспільству.

Отже, підводячи підсумки, слід зазначити, що основні аспекти розвитку та підвищення конкурентоспроможності інтелектуального підприємництва мають соціальну спрямованість, яка в свою чергу, при реалізації, стає найголовнішою конкурентною перевагою, та забезпечує сталий розвиток як підприємству так й суспільству в цілому. 


\section{Література:}

1. Охріменко О.О., Іванова Т.В. Соціальна відповідальність: навч. посіб. Національний технічний університет України «Київський політехнічний інститут». 2015. $180 \mathrm{c}$.

2. Петренко В.О. Фонарьова Т.А. Устінов А.А. Моделювання процесу страхування об’єктів права інтелектуальної власності. «Вчені записки Таврійського національного університету імені В.I. Вернадського. Серія: Економіка і управління». 2021. Том 32 (71). № 3.

3. Петренко В.О., Фонарьова Т.А., Суржиков М.В. До питання управління інноваційним розвитком промислових підприємств України. Матеріали ХІІ Міжнар. наук.-практ. конф. "Сучасні інформаційні технології в економіці та управлінні підприємствами, програмами та проектами». 8-12 вересня 2014. Харків : «XAI», 2014. 130 с. С. 81-82.

4. Ковтуненко Ю.В. Теоретико-методологічні засади диверсифікації інноваційного розвитку бізнес-структур в умовах інтелектуалізації економіки. Дисертація д.е.н. спец. 08.00.04. Одеський національний політехнічний університет, Одеса, 2019.

5. Фонарьова Т.А., Устінов А.А, Бушуєв К.М., Петренко В.О. Трансфер технологій, як інструмент управління конкурентоспроможністю в інтелектуальному підприємництві. «Управління проектами у розвитку суспільства. Тема: «Управління проектами в умовах пандемії COVID-19»»: тези доповідей. Київ: КНУБА, 2021. С. 296-301. 